\title{
Suradnja civilnog društva $i$ javne uprave $u$ postupcima savjetovanja sa zainteresiranom javnošću
}

\section{Berislav Mance*}

\author{
UDK $\quad 35.075 .7:: 323.21$ \\ $342.25:: 323.21$ \\ Original scientific paper/izvorni znanstveni rad \\ Received / primljeno: 27.10.2016. \\ Accepted / prihvaćeno: 15. 3.2017.
}

Analizira se suradnja javne uprave i organizacija civilnog društva u procesu odlučivanja. Snaženje koncepta regulacijske države mijenja ulogu javne vlasti u procesu odlučivanja. To se posebno očituje kroz širenje broja akera koji sudjeluju u izradi politika i odluka. Europska unija razvija mogućnosti i načine putem kojih razne organizacije civilnog društva imaju priliku dati svoje mišljenje o donošenju određene odluke. Republika Hrvatska pokušava slijediti taj trend definiranjem odredbi o postupcima savjetovanja sa zainteresiranom javnošću i uspostavljanjem mehanizama suradnje s organizacijama civilnog društva i drugim akterima na izradi zakona, drugih propisa i akata. Također se analiziraju formalne mogućnosti i stvarna participacija civilnog društva u postupcima savjetovanja sa zainteresiranom javnošću te odnos s javnom vlasti u izradi odluka. Analiziraju se instrumenti savjetovanja

* This paper received the "Eugen Pusić" Award in the category of best student scientific papers by the Institute of Public Administration in Zagreb, Croatia. - Radu je 2016. dodijeljena godišnja nagrada »Eugen Pusić« Instituta za javnu upravu u kategoriji najboljeg studentskog znanstvenog rada.

${ }^{* *}$ Berislav Mance, stručni specijalist javne uprave, Zagreb (Graduated Specialist of Public Administration, Zagreb, Croatia, e-mail: berkic1604@gmail.com) 
sa zainteresiranom javnošću u EU-u i Hrvatskoj. Upozorava se na određene probleme u regulaciji i provedbi instrumenta te se predlažu rješenja za poboljšanje.

Ključne riječi: civilno društvo, savjetovanje, zainteresirana javnost, postupak odlučivanja, javne konzultacije

\section{Uvod}

Uloga javne vlasti u društvu promijenila se tijekom posljednjih desetljeća. Kvaliteta donesenih odluka postaje jedan od ključnih faktora razvoja i funkcioniranja gospodarstva. Sve je značajnije pitanje legitimiteta procesa odlučivanja i različitih propisa kao produkta tog procesa. Naglasak je na postupku izrade i donošenja odluka, stvaranju politika i javnom upravljanju. Uloga države se reducira te ona od centralnog postaje samo jedan od aktera u regulacijskom procesu u koji se uključuju i predstavnici zainteresirane javnosti, građani, razne udruge i organizacije civilnog društva. Aktivnost civilnog sektora raste, a mogućnosti i značenje njihova utjecaja na donošenje odluka proširuju se i približavaju samom žarištu političkog odlučivanja. U radu se analizira odnos civilnog sektora i javne uprave u policy procesu. Putem mnogobrojnih regulacijskih inovacija pokušavaju se uspostaviti mehanizmi koji će proširiti krug aktera koji utječu na donošenje odluka te tako poboljšati njihov sadržaj i legitimitet. Jedan od najvažnijih instrumenata su javna savjetovanja u postupcima odlučivanja. Rad analizira razvoj instrumenta i njegovo provođenje kao dijela politike bolje regulacije Europske unije (EU) te se analizira model savjetovanja sa zainteresiranom javnošću u postupcima donošenja zakona, drugih propisa i akata u Republici Hrvatskoj.

\section{Participacija civilnog društva u odlučivanju Europske unije}

\subsection{Suradnja Europske unije i civilnog društva u izradi propisa}

Posljednjih petnaestak godina EU kontinuirano razvija konzultacije sa zainteresiranom javnošću u okviru politike bolje regulacije. ${ }^{1} \mathrm{U}$ skladu s

${ }^{1}$ Jedan je od važnijih ciljeva jačanje tzv. »ulaznog legitimiteta (Scharpf, 1997), i to najviše provođenjem javnih konzultacija sa zainteresiranom javnošću. 
načelom otvorenosti i teorijom otvorene javne vlasti (Bardet, 2012), EU pokušava prevladati demokratski deficit uključivanjem civilnog društva ${ }^{2} \mathrm{u}$ postupke političkog odlučivanja s ciljem povećanja demokratičnosti, razumljivosti i prihvatljivosti odluka. Europska komisija (EK) uspostavila je 1996. normativni okvir koji definira dijalog s organizacijama civilnog društva (Smismans, 2003) u provedbi socijalnih politika EU-a, a područje suradnje s vremenom se proširivalo pa je $2000 .^{3}$ EK temeljitije uredilo odnose s civilnim društvom, načine na koji dobiva informacije i strukture putem kojih EK konzultira njihove predstavnike.

Pri formiranju odluka EU nastoji provoditi model refleksivne deliberativne poliarhije (Barić \& Dobrić, 2012), koji najviše podržava participaciju civilnog društva u procesima političkog odlučivanja. Organizacije civilnog društva tako ostvaruju utjecaj na odlučivanje neformalnim mehanizmima (npr. lobiranje), formalnim načinima posredno putem reprezentativnih institucija te neposredno sudjelovanjem u postupcima savjetovanja. Odlukom Vijeća EU (Odluka 2004/100/EC) 2004 pokreće. se program koji promovira građansku participaciju i educira građane o ciljevima i institucijama EU-a, a program EACEA-e Europa za građane potiče razvoj, izradu projekata i međusobnu suradnje civilnog društva u zemljama članicama.

Bijela knjiga o europskoj vladavini iz 2001 usmjerena. je uz ostalo prema decentralizaciji izrade politika, transparentnosti informacija i donošenja odluka. Načela dobrog upravljanja ${ }^{4}$ naglašavaju važnost izgrađenog i uređenog odnosa s civilnim društvom i njegovu ulogu u kreiranju odluka EU-a. Ističe se da je kulturu konzultacija i dijaloga primjerenije graditi putem »mekših « instrumenata poput kodeksa ponašanja s minimalnim standardima, a ne krutim zakonskim pravilima (EK, 2001, str. 9). Kritike Bijele knjige s aspekta odnosa prema civilnom društvu ističu simplificirani pogled EK-a na civilno društvo (Butković, 2004), rizik od moguće prevelike formalizacije postupaka savjetovanja, pretvaranja u mehanizam za potvrđivanje legitimiteta odluka koje se zapravo donose drugdje te naglašavaju zapostavljanje drugih metoda uključivanja aktera u upravljanje i odlučivanje (Butković, 2004), no najveća zamjerka usmjerena je prema pravno neobvezujućem karakteru dokumenta. EK je 2002..$^{5}$ predložila te-

2 Dva su koncepta pojma civilnog društva u EU-u: znanstveni (akademski) (Heidbreder, 2012) i onaj koji na civilno društvo gleda kao na aktere koji doprinose kvaliteti i legitimitetu policy procesa (Heidbreder, 2012).

${ }^{3}$ COM (2000) 11 final, 18 January 2000.

${ }^{4}$ Otvorenost, sudjelovanje, odgovornost, učinkovitost i koherentnost.

${ }^{5}$ COM (2002) 0704 final. 
meljna načela ${ }^{6}$ i minimalne standarde ${ }^{7}$ koji se moraju osigurati u provodenju postupaka savjetovanja te ih 2007. revidirala i potvrdila, a nadzor njihove primjene postao je dio nadležnosti Odbora za nadzor regulative (Renda, 2008).

Ugovor iz Lisabona određuje jasan smjer daljnje izgradnje odnosa s građanima i civilnim društvom (čl. 11.). Koncept pametne regulacije dodatno ojačava intenzitet i širi sudjelovanje javnosti na sve faze procesa odlučivanja, posebice u fazama implementacije i evaluacije. Savjetovanja su i u fokusu programa REFIT, a novi međuinstitucijski sporazum EK, Parlamenta i Vijeća o boljoj izradi zakonodavstva spominje i savjetovanja sa zainteresiranom javnošću (Agreement, t. 19) naglašavajući njihovu nezaobilaznost u izradi odluka čija se kvaliteta zasniva, između ostalog, na informacijama dionika.

\subsection{Savjetovanja institucija EU sa zainteresiranom javnošću}

Postupak javnog savjetovanja jedan je od najvažnijih instrumenata politike bolje regulacije. Savjetovanja su dio postupka procjene učinka propisa ${ }^{8}$ koji se provodi za zakonodavne prijedloge EK-a, nezakonodavne inicijative te provedbene i delegirane akte ${ }^{9}$ za koje se pretpostavlja da bi mogli prouzročiti značajne gospodarske, ekološke ili socijalne učinke. Tijekom 2014. provedeno je 59 postupaka, 2015. samo 16 postupaka, a u prvih pet mjeseci 2016. 12 postupaka procjene učinaka propisa. ${ }^{10}$ EK je du-

${ }^{6}$ Načelo sudjelovanja, zatim načelo učinkovitosti, načelo koherentnosti te načelo otvorenosti i odgovornosti.

7 Što jasnije definirati i učiniti javno dostupnim kontekst, sadržaj, ciljeve, načine davanja mišljenja i druge pojedinosti postupaka savjetovanja; osigurati mogućnost sudjelovanja svim relevantnim akterima (posebno budućim adresatima odluka o kojima se provodi savjetovanje); javno objaviti detalje o savjetovanju putem što više raspoloživih sredstava komunikacije; ostaviti dovoljan vremenski rok, minimalno osam tjedana sa mogućnošću produljenja po potrebi i do 12 tjedana (Musa, 2015) za dostavu mišljenja, prijedloga i primjedaba; javno objaviti zaključke nakon provedenih konzultacija; jednako razmatrati i uzimati u obzir sve prijedloge te argumentirano odgovoriti na sve, a posebno na one koji nisu usvojeni ili su samo parcijalno usvojeni.

${ }^{8}$ Savjetovanja se koriste i u drugim slučajevima kada EK ima namjeru donošenja nekog dokumenta (Musa, 2015).

9 Javnost se početnom procjenom učinka (Inception Impact Assessment) informira o planiranim procjenama učinaka propisa. Unutar tih dokumenata nalaze se sve potrebne informacije o planiranim savjetovanjima sa dionicima, rokovima i načinima sudjelovanja..

$10 \mathrm{http} / / /$ ec.europa.eu/smart-regulation/impact/ia_carried_out/cia_2016_en.htm. 
žan provoditi savjetovanja u skladu sa čl. 11. Ugovora i Protokolom br. 2 o primjeni načela proporcionalnosti i supsidijarnosti, a javnu raspravu o pitanjima vezanima za pojedinu regulacijsku aktivnost i područje koje se njome namjerava urediti pokreće »priopćenjima, izvještajima te zelenim i bijelim knjigama« (Musa, 2015, str. 9). Otvorena internetska savjetovanja provode se, osim za već navedene inicijative za koje se provodi procjena učinaka, za inicijative za koje se provode evaluacije i provjere prikladnosti (Fitness Checks) i u okviru zelenih knjiga nakon što ih EK usvoji. ${ }^{11}$

Web stranica Vaš glas u Europi ${ }^{12}$ omogućuje vrlo jednostavan pristup svim aktualnim postupcima savjetovanja i informacijama vezanim uz njih na jednom mjestu. Građani registracijom u sustav Commission at work-Notifications $^{13}$ dobivaju pravovremene informacije o planovima i pripremi novih inicijativa i postupcima savjetovanja u kojima mogu sudjelovati. Korisno za udruge civilnog društva, nevladine organizacije i slična udruženja jest registriranje u Registar transparentnosti. ${ }^{14}$ To su javne web stranice koje omogućuju preglednost registriranih organizacija, interesa koje one zastupaju na razini EU-a i drugih podataka čija je transparentnost potrebna i korisna. Postoje i drugi instrumenti (npr. konzultacijske grupe) putem kojih je dionicima omogućeno iznošenje mišljenja i sudjelovanje (Musa, 2015).

Posljednjih godina EK je izradilo niz dokumenata kojima pokušava usavršiti postupke savjetovanja sa zainteresiranom javnošću, pojasniti i približiti metodologiju i instrumente svojim službenicima, osoblju i svim dionicima izvan institucija EU-a koji sudjeluju u tim postupcima. Sredinom 2015. objavljene su Smjernice za bolju regulativu ${ }^{15}$ unutar kojih se nalaze upute i objašnjenja namijenjena svim zaposlenicima EU-a koji su uključeni u pripremu zakonodavstva, politika ili u njihovu provedbu. Objavljen je i Instrumentarij za bolju regulativu (Better Regulation »Toolbox«), kao tehnički razrađenija i detaljnija potpora i razrada Smjernicama. Jednostavna shema za vođenje postupka savjetovanja (Europska komisija, 2014) strukturira postupak u ovih deset koraka:

- Jasno definirati ciljeve koji se namjeravaju ostvariti savjetovanjem

\footnotetext{
11 Trajanje navedenih e-savjetovanja je 12 tjedana.

12 http://ec.europa.eu/yourvoice/index_hr.htm.

$13 \mathrm{https}: / /$ webgate.ec.europa.eu/notifications/homePage.do?locale=en\#en.

${ }^{14} \mathrm{http}: / /$ ec.europa.eu/transparencyregister/public/homePage.do?redir=false\&locale= en\#en.

15 SWD (2015) 110 final.
} 
- Prepoznati dionike koji su potencijalni sudionici savjetovanja i jasno ih odrediti u službenom dokumentu savjetovanja ili na web stranici savjetovanja

- Odabrati najučinkovitije i najprimjerenije metode i instrumente

- Odrediti jasne rokove savjetovanja, posebice vrijeme početka i završetka trajanja savjetovanja te sve bitne rokove unutar tog perioda

- Urediti web stranicu savjetovanja koja će sadržavati sve potrebne informacije i upute o postupku, rokovima, aktivnostima i drugim potrebnim podacima za zainteresirane sudionike savjetovanja, prezentirane na razumljiv način svakome

- Javno objaviti informaciju o održavanju postupka savjetovanja pri čemu je potrebno služiti se svim dostupnim i primjerenim sredstvima komunikacije kako bi se informirao što veći broj potencijalno zainteresiranih građana i dionika

- Potvrditi zaprimanje svih očitovanja sudionika savjetovanja i javno objaviti sva očitovanja nakon završetka postupka savjetovanja

- Provesti temeljitu analizu i ispitivanje prikladnosti odnosno mogućnosti konstruktivne upotrebe svih prijedloga, mišljenja i kritika dobivenih u postupku savjetovanja

- Obavijestiti sudionike savjetovanja o očitovanjima koja su prihvaćena te razmjerima prihvaćanja i o očitovanjima koja nisu uzeta u obzir uz detaljno objašnjenje razloga radi pružanja povratne informacije i transparentnosti

- Pravovremeno evaluirati postupak, za vrijeme njegova trajanja i nakon završetka.

Navedene korake potrebno je ostvariti bez izostavljanja bilo kojeg dijela, zbog mogućnosti znatnog umanjenja kvalitete i vjerodostojnosti postupka, a gubitak transparentnosti i otvorenosti postupka je neizbježan.

Napredak EU-a na području uključivanja zainteresirane javnosti, organizacija civilnog društva i drugih dionika vidljiv je i nedvojben. Iako prostora za poboljšanja ima još mnogo, nikako ne bi trebalo zanemariti pozitivan utjecaj EU-a prema drugima a posebno državama u razvoju, koje bi se često morale koristiti iskustvom EU-a kao orijentacijskom vodiljom u izgradnji, organizaciji i razvijanju vlastitih sustava savjetovanja sa zainteresiranom javnošću. S druge strane, EU bi trebala usmjeravati izgradnju što koherentnijih nacionalnih modela i politika savjetovanja ${ }^{16}$ između država

\footnotetext{
${ }^{16} \mathrm{U}$ istraživanju provedenom među zemljama koje su postale članice EU-a 2004. pokazalo se da, iako postupak savjetovanja većinom postoji kao obvezatni element, ne postoji ujednačen pristup tom alatu (Banić, 2009).
} 
prema modelu savjetovanja EU-a kako bi građani na svim razinama ostvarivali mogućnost što sličnije kvalitete participacije.

Određeni problemi unutar sustava savjetovanja sa zainteresiranom javnošću u EU-u i dalje postoje: a) selektivnost u interakciji sa zainteresiranim skupinama; b) nejednaka dostupnost postupaka savjetovanja; c) prevelik fokus na kompeticiju među civilnim društvom i d) slaba odazivnost na sudjelovanje u postupcima savjetovanja.

Često tijela EU-a bolje i više surađuju s organizacijama civilnog društva koja su im poznatija, vidljivija, s onima s kojima imaju frekventan i uzajamno podržavajući odnos. Civilni sektor na području EU-a vrlo je velik, međutim potrebno je svako mišljenje i prijedlog uzimati sa jednakom dozom razumijevanja i svakog novog sudionika u savjetovanju na jednak način percipirati, komentare vrednovati prema objektivnom mjerilu njihove kvalitete i konstruktivnosti, posebno zato što gotovo svakodnevno nastaju nova područja interesa koja je potrebno regulirati, a sukladno tome pojavljuju se mnogi novi predstavnici zainteresirane javnosti koji ih zastupaju u postupcima savjetovanja.

Dostupnost postupaka savjetovanja znatno ovisi o količini sredstava koju pojedina organizacija ima za provođenje policy analize i mogućnostima za financiranje vlastitog predstavništva organizacije civilnog društva u Bruxellesu. Bogatije organizacije time postaju prisutnije, a ostvarivanje njihovih interesa izglednije. EU bi morala što više pokušavati amortizirati tu nejednakost u pripremama i provođenju konzultacija te omogućiti svim organizacijama što jednakiju dostupnost mehanizmima i podacima savjetovanja, posebice onima iz slabije razvijenih država članica.

Ističe se da je, umjesto nastanka svojevrsnog homogenog civilnog društva Europe, omogućavanjem sudjelovanja zainteresirane javnosti u kreiranju odluka formirana arena za kompeticiju među organizacijama civilnog društva i njihovim interesima, a stare elitističke strukture održale su se udruživanjem s novim profesionalnim organizacijama civilnog društva (Heidbreder, 2012). Natjecanje pridonosi demokratičnosti, no ako se pretvori u primarni cilj, može se izgubiti svrha javnih konzultacija u smislu smanjivanja demokratskog deficita, a interesi i aktivnosti građana stavljeni su u drugi plan zbog borbe za utjecaj i prevlast organizacija iz različitih država i interesnih grupacija. EU bi trebala aktivno poticati konstruktivniju kompeticiju, ali i uzajamnu suradnju među sudionicima u svim postupcima koje provodi te više podržavati dijalog, a što manje atmosferu interesne utakmice među akterima. 
Velik je problem nerijetko vrlo slab odaziv na sudjelovanje u savjetovanjima. ${ }^{17}$ Za funkcioniranje tog instrumenta potrebna je uključenost obje strane (Bardet, 2012) pa EU mora nastojati neprekidno poticati dionike i nadalje graditi i razvijati svoju ulogu u ovim postupcima. Povećanje intenziteta korištenja tehnološki naprednijim i aktualnijim načinima objavljivanja savjetovanja i komunikacije (npr. društvene mreže) moglo bi smanjiti navedeni problem. Sadržaji trebaju biti lako dostupni, vidljivi i razumljivi svima, s jasnim i ažurnim uputama, a pomoću društvenih mreža moguće je razvijati frekventnu i dvosmjernu komunikaciju. Dokumente i upute trebalo bi prevoditi na što više službenih jezika EU-a i prilagoditi pojedinim skupinama ljudi kako bi se sadržaji politika i odluka EU-a više približili te kako bi se osigurao prijenos informacije o provedbi savjetovanja prema što većem broju potencijalnih dionika i građana koji bi bili zainteresirani sudjelovati.

\section{Savjetovanja sa zainteresiranom javnošću u postupcima donošenja zakona, drugih propisa i akata u Hrvatskoj}

Civilno se društvo u Hrvatskoj (RH) razvija različitim intenzitetom posljednja dva i pol desetljeća. Na to je utjecao niz faktora, poput rata 1990ih, procesa pristupanja EU-u, povijesnog nasljeđa bivšeg nedemokratskog sustava (Barić \& Dobrić, 2012), nesudjelovanje RH u programu EU-a Phare, raširenost pogleda građana na te organizacije kao antivladine (Bežovan, 2003) i protuvladine, osiromašenje srednje klase (Puljiz, 2000). Zbog tih, ali i drugih razloga, tijekom 1990-ih i u ranom početku 2000ih nije bilo snažnijeg razvoja civilnog društva, naprotiv, razvoj se krajem 1990-ih dodatno usporio.

Izvjesna pozitivna ostvarenja ipak su postignuta pa je uredbom (NN 132/1998) 1998. osnovan Ured Vlade RH za udruge (Ured) sa svrhom obavljanja stručnih poslova Vlade u vezi sa stvaranjem uvjeta za partnerske odnose i međusektorsku suradnju s neprofitnim sektorom, posebno s udrugama. ${ }^{18}$ Nešto kasnije osnovana je Nacionalna zaklada za razvoj civil-

$17 \mathrm{http} / / / \mathrm{ec}$.europa.eu/smartregulation/impact/docs/contributions/summary_responses_stakeholder_consultation_guidelines_public_consultation_en.pdf.

18 Više od godinu dana prije osnivanja Ureda donesen je prvi zakon koji uređuje status udruga u RH (NN 70/97). 
nog društva (NN 173/03), a potom i Savjet za razvoj civilnog društva (NN 140/09) te Gospodarsko-socijalno vijeće (NN 149/09). Početkom 2001. usvojen je Program suradnje Vlade RH i nevladinog, neprofitnog sektora u RH čiji su središnje provedbene institucije Savjet za razvoj civilnog društva i Ured za udruge. Dokument je neobvezujući, no u njemu su značajne smjernice za pružanje potpore i daljnjem razvoju civilnog društva.

Velik broj reformi u RH inicirale su međunarodne organizacije uvjetovanjem davanja novčanih kredita ili EU usklađivanjem zakonodavstva s europskom pravnom stečevinom u okviru pregovora za članstvo u EU-a. Početkom procesa pristupanja EU-a otvorila su se vrata participaciji civilnog društva u odlučivanju (Vidačak \& Škrabalo, 2014). No, iako je proces europeizacije i pregovora s EU-om ponudio znatan potencijal za uvođenje temeljitih promjena u javnu upravu, transparentnost rada javnog sektora i druga područja, dublje promjene političke i administrativne kulture zatvorenosti i tajnosti ipak nisu uspjele. Razlog je izostanak prije svega političke volje koja bi pokrenula intenzivnije promjene, umjesto čega su provedene uglavnom formalne prilagodbe nužne za postizanje cilja pregovora, a uključivanje civilnog društva i javnosti u pregovore izostalo je gotovo potpuno. ${ }^{19}$ Upravo je izostanak uspostavljanja kvalitetne suradnje političkih i administrativnih elita s civilnim društvom i građanima označen kao najslabija točka pregovora o pristupanju EU-a (Vidačak \& Škrabalo, 2014). Ipak, mnoge su organizacije uspostavile dobre odnose s interesnim organizacijama na razini EU-a, međusobno komunicirale i razmjenjivale iskustva (Vidačak, 2011) te na taj način povećavale vlastite kapacitete za sudjelovanje u postupcima odlučivanja.

\subsection{Uključivanje civilnog društva u postupke savjetovanja sa zainteresiranom javnošću}

Početkom službenih pregovora s EU-om 2005. paralelno je u RH započela i regulacijska reforma. ${ }^{20}$ Nedostatak institucionaliziranih odnosa državnih i nedržavnih aktera u zakonodavnom procesu bio je jedan od najvećih

19 Vlada je, na početku pregovaračkog procesa, formalno prepoznala civilno društvo kao aktera kojemu namjenjuje vrlo bitnu ulogu tijekom procesa. Komunikacijskom strategijom informiranja hrvatske javnosti o procesu pristupanja EU-u istaknuta je važnost suradnje i partnerstva civilnog društva s Vladom u promicanju što boljeg razumijevanja cjelokupnog procesa u hrvatskoj javnosti i među građanima (Horvatić, 2006). 2009).

${ }^{20}$ Osim EU, reformu u RH inicirali su USAID, Svjetska banka i OECD (Petek, 
indikatora nužnosti regulacijske reforme u RH (Petek, 2009). Reforma je započela 2006. fazom upravnog pojednostavljenja pokretanjem projekta Hitrorez, a drugo područje regulacijske reforme u RH bilo je upravo informiranje i uključivanje zainteresirane javnosti u postupke izrade propisa.

Kodeks savjetovanja sa zainteresiranom javnošću u postupcima donošenja zakona, drugih propisa $i$ akata. Kodeks savjetovanja sa zainteresiranom javnošću u postupcima donošenja zakona, drugih propisa i akata (Kodeks) bio je predviđen Nacionalnom strategijom stvaranja poticajnog okruženja za razvoj civilnog društva za razdoblje 2006.-2011., Strategijom reforme državne uprave za razdoblje 2008.-2011., a temelji se i na Bijeloj knjizi o europskoj vladavini, Općim načelima i minimalnim standardima konzultiranja zainteresiranih strana EK-a i Kodeksu sudjelovanja civilnog društva u procesu donošenja odluka Vijeća Europe (Barić \& Dobrić, 2012). Donesen krajem 2009. ${ }^{21}$ kao dio Akcijskog plana za suzbijanje korupcije, primarna je zadaća Kodeksa omogućavanje aktivnije participacije zainteresirane javnosti u postupcima izrade propisa i akata, ali i bolji pristup građana državnim tijelima. U Kodeksu su definirane mogućnosti sudjelovanja javnosti u postupcima odlučivanja kroz četiri razine različitog intenziteta: 1) informiranje javnosti; 2) savjetovanje; 3) aktivno uključivanje i 4) partnerstvo. Definirana su i Opća načela za savjetovanje: a) sudjelovanje, b) povjerenje, c) otvorenost, d) odgovornost i e) djelotvornost.

Kodeks ističe nekoliko minimalnih standarda i mjera kojih se treba pridržavati pri provođenju savjetovanja: 1) pravodobno informiranje o planu donošenja zakona, drugih propisa i akata, 2) dostupnost i jasnoća sadržaja postupaka savjetovanja, 3) jasno naznačeni rok provedbe internetskog i drugih oblika savjetovanja (minimalno 15 dana), ${ }^{22} 4$ ) povratna informacija o učincima provedenog savjetovanja i 5) usklađenost primjene standarda i mjera savjetovanja u državnim tijelima. Namjena primjene Kodeksa nije isključivo vezana za fazu neposredne izrade propisa i akata, već bi se trebao koristiti i pri definiranju stavova i ciljeva (Musa, 2015). Adresati primjene su državna tijela, tijela jedinica lokalne i područne (regionalne) samouprave (JLS) te pravne osobe u određenim slučajevima. ${ }^{23}$ Glavno

${ }^{21}$ U izvješću o napretku reforme hrvatske javne uprave iz 2010. SIGMA je donošenje Kodeksa ocijenila pozitivnim (Lalić Novak, 2010).

22 Najčešći rok je 30 dana (Koprić et al., 2014).

23 Pravne osobe s javnim ovlastima Kodeks primjenjuju »u postupcima donošenja općih akata kojima se uređuje pitanje iz njihovog djelokruga i kojima se neposredno ostvaruju potrebe građana ili druga pitanja od interesa za opću dobrobit građana i pravnih osoba na njihovu području odnosno području njihove djelatnosti« (NN 140/09, t. 9). 
koordinativno tijelo za primjenu Kodeksa je Ured koji na svojoj web stranici objavljuje sve važne informacije i upute vezane za postupke savjetovanja s udrugama civilnog društva ${ }^{24}$ i priprema godišnja izvješća o provedbi Kodeksa. Pravilnu primjenu Kodeksa u tijelima javne vlasti osiguravaju koordinatori, ${ }^{25}$ službenici koji provode postupke u svojim organizacijama. Ured je 2010. izdao publikaciju Smjernice za primjenu Kodeksa savjetovanja sa zainteresiranom javnošću u postupcima donošenja zakona, drugih propisa i akata i izradio program edukacije koordinatora postupaka savjetovanja u državnoj upravi. Na temelju Kodeksa i Smjernica u okviru projekta izrađen je Priručnik za savjetovanja namijenjen koordinatorima savjetovanja. Državna škola za javnu upravu i Ured tijekom 2013. organizirali su niz seminara radi daljnjeg usavršavanja koordinatora (Vidačak, 2013).

Jedan od najvećih nedostataka ovakvog načina regulacije postupaka savjetovanja sa zainteresiranom javnošću jest to što za nepridržavanje odredaba Kodeksa nisu predviđene pravne sankcije. Zakonskim odredbama nije bila propisana obveznost provođenja postupaka savjetovanja. Obveza provođenja postupaka savjetovanja postojala je, doduše, pri donošenju propisa i akata koji mogu imati utjecaj na okoliš u skladu s odredbama Arhuške konvencije od ratifikacije tek 2006. odnosno propisivanja obveze savjetovanja Zakonom o zaštiti okoliša (NN 110/07). Prema Kodeksu je, ipak, bilo moguće u svakom pojedinom slučaju odlučivati hoće li se ili neće provoditi savjetovanje.

Efikasnost i efektivnost takvog načina uključivanja javnosti ${ }^{26}$ i civilnog društva u procese odlučivanja nisu bili na zadovoljavajućoj razini.

Zakon o pravu na pristup informacijama ${ }^{27}$ (ZPPI) iz 2013. propisuje obveznu provedbu savjetovanja putem interneta odnosno prekršajnu sankciju onim tijelima javne vlasti koja to ne učine. Time je riješen jedan od velikih problema Kodeksa, nepostojanje odredbe o pravnom sankcioniranju za neprovođenje postupaka savjetovanja sa zainteresiranom javnošću. Dodatno, Hrvatski sabor je Poslovnikom (NN 81/13; čl. 174/4) odredio

${ }^{24}$ https://udruge.gov.hr.

25 Popis koordinatora u tijelima državne uprave nalazi se na web stranici Ureda za udruge. Kako bi koordinatori što kvalitetnije provodili postupke savjetovanja, organizirani su mjesečni sastanci koordinatora (peer-to-peer network) sa svrhom razmjene znanja i iskustava iz prakse.

${ }^{26}$ Izostanak reguliranja obveze provođenja postupaka savjetovanja i definiranje sankcija za neprovođenje pokazatelji su očite razlike u deklarativnim stavovima o važnosti i potrebi uključivanja civilnog društva u odlučivanje i stvarne prakse (Škrabalo, 2012).

27 Prvi zakon kojim je regulirano ovo pravo donesen je 2003. (NN 172/2003). Promjenom Ustava 2010. pravo na pristup informacijama javnog sektora uneseno je u u tekst Ustava. 
obvezu predlagatelja zakona da uz potrebnu dokumentaciju podnese i izvješće o provedenom savjetovanju. ZPPI je propisao i obveze objave plana savjetovanja na internetskim stranicama radi transparentnosti i mogućnosti pripreme dionika savjetovanja za participiranje, produljenje roka u odnosu prema roku propisanom Kodeksom na 30 dana i niz drugih obveza.

Prošlogodišnjim izmjenama ZPPI-ja, jasnije su definirana tijela javne vlasti koja su obvezna provoditi savjetovanja sa zainteresiranom javnošću određenjem pojma tijela javne vlasti, a detaljnije je uređena i obveza proaktivne objave informacija. Aktivirana je aplikacija e-Savjetovanja ${ }^{28} \mathrm{u}$ okviru Središnjeg državnog portala, putem koje tijela državne uprave provode svoja savjetovanja. Putem aplikacije postupke savjetovanja mogu provoditi i svi ostali obveznici provodenja savjetovanja ako ih ne provode putem svojih internetskih stranica. Za koordinaciju postupaka internetskih savjetovanja nadležan je Ured za udruge. Putem aplikacije svim registriranim korisnicima omogućen je pristup podacima o svim trenutačno aktivnim savjetovanjima u državnim tijelima te lakši postupak davanja prijedloga i mišljenja, ali i lakši način objavljivanja izvješća o rezultatima savjetovanja. U godinu dana funkcioniranja putem aplikacije provedeno je ukupno 506 postupaka savjetovanja od 43 državna tijela. ${ }^{29}$

Krajem 2011. RH se uključila u svjetsku inicijativu Partnerstvo za otvorenu vlast ${ }^{30} \mathrm{~s}$ ciljem osnaživanja transparentnosti i otvorenosti javne vlasti te jačanja i uključivanja građana i civilnog društva. Strategije suzbijanja korupcije (NN 26/15; NN 75/15) govore o potrebi povećanja transparentnosti rada i odlučivanja JLS i ističu suradnju s civilnim društvom u odlučivanju vrlo važnom u borbi protiv problema korupcije.

Postupak savjetovanja sa zainteresiranom javnošću kao dio procjene učinaka propisa. Instrument savjetovanja sa zainteresiranom javnošću ugrađen je u Zakon o procjeni učinaka propisa (NN 90/11) (ZPUP) iz 2011. kojim se procjenjuju mogući učinci propisa na gospodarstvo, socijalnu skrb i zaštitu okoliša. Doprinos razvoju savjetovanja sa zainteresiranom javnošću ovdje se ističe kao poseban cilj provođenja procjene učinaka propisa. Tijekom postupka procjene učinaka propisa postoji nekoliko faza u kojima zainteresirana javnost ima mogućnost ostvariti svoje sudjelovanje, dati mišlje-

\footnotetext{
${ }^{28} \mathrm{https} / / /$ savjetovanja.gov.hr.

${ }^{29} \mathrm{U}$ godinu dana postojanja aplikacija broji 4.568 registriranih korisnika: 3.200 pojedinaca, 599 trgovačkih društava, 232 udruge, 174 ustanove, 143 obrta, 37 zadruga i niz drugih pravnih osoba (https://savjetovanja.gov.hr/vijesti/godina-dana-rada-portala-e-savjetovanja-1145/1145).

${ }^{30} \mathrm{http}: / / \mathrm{www}$. opengovpartnership.org.
} 
nje, prijedlog ili kritiku te dobiti informaciju o sadržaju nacrta prijedloga propisa. Stručni nositelj izrade propisa obvezan je objaviti prijedlog plana propisa, u kojima se navodi popis onih za koje će se provoditi procjena učinaka, na svojoj internetskoj stranici u trajanju od minimalno 15 dana (NN 90/11; čl. 12/1). Na taj se način svi zainteresirani akteri informiraju o propisima koje pojedini nositelj izrade namjerava izraditi a za koje se planira provoditi procjena učinka te im je osigurano vrijeme za pripremu mišljenja i prijedloga. U postupku izrade nacrta prijedloga iskaza nositelj izrade provodi svoje konzultacije ${ }^{31}$ s dionicima ${ }^{32}$ (NN 90/11, čl. 18/3) na temelju čega izrađuje izvješće o održanim konzultacijama s dionicima. ${ }^{33}$

Postupak savjetovanja sa zainteresiranom javnošću mora se provesti u trajanju od 30 dana, a prema ocjeni potrebe nositelja izrade taj se rok može produljiti. Zakon i Uredba ne definiraju vremensko ograničenje produžetku trajanja savjetovanja niti su definirani slučajevi koje bi nositelj izrade mogao ocijeniti kao opravdane za produljenje roka pa se može zaključiti da je ovdje zakonodavac ostavio diskrecijsku mogućnost ocjene nositelju izrade. Unutar roka za održavanje savjetovanja nositelj izrade putem koordinatora za savjetovanje (koordinator) dužan je održati barem jedno, a ovisno o složenosti materije i više javnih izlaganja materije koja je predmet savjetovanja (NN 90/11; čl. 19/3.) radi pobližeg upoznavanja s materijom, o čemu je dužan sastaviti zapisnik (NN 66/12; čl. 19/3.). Nakon završetka savjetovanja koordinator razmotra sve primjedbe, prijedloge i mišljenja prikupljene tijekom savjetovanja te je obvezan davatelje primjedaba i prijedloga, ali i ukupnu javnost, obavijestiti o prihvaćenim i odbijenim primjedbama, prijedlozima i mišljenjima putem internetske stranice (čl. 19/4.). Nakon izrade propisa i prijedloga iskaza, nositelj izrade dužan je o njima provesti javnu raspravu u trajanju od 15 do 30 dana tijekom koje je javnost i zainteresirana javnost pozvana na davanje svojeg mišljenja.

Civilno društvo i cjelokupna javnost putem ZPUP-a osnažili su svoju ulogu u izradi regulative, i to prvenstveno tako da su tijela javne vlasti ovlaštena za izradu propisa obvezna provoditi savjetovanje sa zainteresiranom javnošću u okviru izrade propisa za koje se provodi procjena učinaka.

31 Pri provedbi konzultacija Uredba propisuje korištenje aktivnih (pisma, e-mail, radni sastanci, okrugli stolovi) i pasivnih metoda (objava materijala na internetskim stranicama) (NN 66/12, čl. 18/3.).

32 Uredba o provedbi postupka procjene učinaka propisa nalaže uključenje što većeg broja relevantnih zainteresiranih dionika (NN 66/12; čl. 18/2.).

33 Izvješće mora uključiti odgovarajuće podatke o svakom dioniku koji je sudjelovao u konzultacijama, problematiku i ciljeve rasprave te navode značajnijih učinaka koje su dionici istaknuli (NN 66/12, čl. 18/4.). 
Problemi u postupcima savjetovanja sa zainteresiranom javnošću. Provedba instrumenta savjetovanja sa zainteresiranom javnošću u RH nailazi na razmjerno velik broj poteškoća i prepreka normalnom i stabilnom funkcioniranju. Probleme možemo podijeliti na sljedeće: a) politički problemi i b) provedbeni problemi.

Politički su problemi: a) nedostatak snažne političke potpore; b) postojeća uloga javne vlasti u donošenju odluka.

Provedbeni su problemi: a) kršenje odredbe o duljini trajanja savjetovanja; b) vrlo slaba provedba savjetovanja u JLS; c) nedovoljna kvantiteta i kvaliteta komunikacije unutar savjetovanja i d) smanjenje rasta broja provedenih savjetovanja.

Savjetovanjima sa zainteresiranom javnošću nužno je potrebna snažna i jasno izražena politička potpora. U RH je tijekom pregovora za pristupanje EU-u gotovo sasvim zanemarena suradnja s civilnim društvom. Formalno, postoji nastojanje da se poveća fokus na postupak, uključivo kreaciju propisa i sudjelovanje drugih aktera u odlučivanju, međutim potpora vlasti uspješnom razvoju instrumenta savjetovanja i dalje je mnogo više načelna i deklarativna nego stvarno prisutna. Nedostatak pravne sankcije u Kodeksu, donošenje iznimno velikog broja zakona po hitnom postup$\mathrm{ku}^{34}$ odnosno znatnog broja zakona za koji se državna tijela jednostavno nisu odlučila provoditi postupak savjetovanja ${ }^{35}$, marginalizacija participacije zainteresirane javnosti u procesima donošenja izvršnih odluka čija je važnost od visokog značenja (Džinić, 2011), manjak strateškog pristupa planiranju te neobjavljivanje nacrta prijedloga zakona dovoljno vremena unaprijed (Barić \& Dobrić, 2012) da bi se omogućila kvalitetna priprema prijedloga svih sudionika samo su neki od razloga koji idu u prilog tvrdnji o nedostatnoj političkoj potpori instrumentu savjetovanja u RH.

Uz to je u regulacijskom procesu dalje percepcija uloge javne vlasti kao nezamjenjivog, golemog i primarnog političkog igrača koji je u najvećoj mjeri samostalan u odlučivanju. U RH je na uključivanje civilnog društva u odlučivanje ponajviše utjecalo djelovanje vanjskih faktora i procesa $u$ kojima se država nalazila, stoga ne treba čuditi održavanje nezanemarivog institucionalnog otpora prema otvaranju, transparentnosti, mijenjanju

\footnotetext{
34 SIGMA je 2011. ustvrdila da se iskorištavanjem hitnog postupka konzultacije sa zainteresiranom javnošću ograničavaju i isključuju iz postupaka izrade propisa te im se umanjuje kvaliteta (SIGMA Assessment Croatia).

35 Tek je za nešto više od trećine svih zakona koji su u 2011. upućeni u zakonodavnu proceduru bilo provedeno savjetovanje sa zainteresiranom javnošću (Musa, 2015).
} 
kulture tajnosti i razvijanju obzirnosti prema sudionicima u odlučivanju. U takvom okruženju kultura participacije građana ne može se razvijati na pravi način, a uloga javne uprave u procesu odlučivanja teško se mijenja i uistinu otvara prema suradnji s drugima.

Druga skupina problema vezana je za provođenje postupaka savjetovanja sa zainteresiranom javnošću. Jedan od najvećih problema je iznimno često izbjegavanje pridržavanja definiranog roka od 30 dana za provođenje savjetovanja. Prema izvješćima o provedbi savjetovanja sa zainteresiranom javnošću u postupcima donošenja zakona, drugih propisa i akata u 2014. odnosno 2015., u 2014. je 52\% svih provedenih postupaka prosječno skraćivano za punih tjedan dana, a broj tako skraćenih postupaka u 2015. povećan je na čak $88 \%$. Takav rastući negativni trend zanemarivanja propisanog roka od 30 dana upozorava na pretjerano zaobilaženje pravilnog provođenja postupaka savjetovanja, pod opravdanjem žurnosti te pozivanjem na odredbe Kodeksa (Izvješće, 2015) iako je u ovom slučaju odredba ZPPI-ja hijerarhijski snažnija i vremenski novija. Takvim se postupanjem suzuje period za konstruktivan dijalog i razmjenu međusobnih mišljenja između aktera. Skraćivanjem predviđenog vremena za savjetovanje umanjuje se vjerojatnost izrade kvalitetnijih alternativnih prijedloga i riješenja, a unutar zainteresirane javnosti dolazi do pada motivacije za aktiviranjem i pojave nesigurnosti u postupcima savjetovanja.

Nepridržavanje odredaba o savjetovanju primjetno je i u (ne)provedbi instrumenta u JLS. Naime, na lokalnoj (regionalnoj) razini izrazito je rašireno zaobilaženje provedbe savjetovanja sa zainteresiranom javnošću, posebice prema Kodeksu, pa su se tako odredbe Kodeksa o postupcima savjetovanja početkom 2011. primjenjivale tek u dva grada i jednoj općini (ODRAZ, 2012). Stanje je krenulo nabolje utvrđivanjem sankcija, no i dalje se situacija nije značajnije popravila. Na lokalnoj i područnoj (regionalnoj) razini prema ZPPI-ju provođeno je u prosjeku jedno savjetovanje po JLS (Izvješće, 2015), što je pokazatelj nepravilnog provođenja zakona i izostanka funkcioniranja mehanizma savjetovanja na razinama vlasti koje su najbliže građanima i u kojima bi sudjelovanje javnosti u izradi riješenja za javne probleme trebalo biti svakodnevna i uobičajena pojava. Ispravnom djelovanju mehanizma savjetovanja sa zainteresiranom javnošću mnogo pridonosi konstruktivna dvosmjerna komunikacija aktera kako bi se ostvarila bit uključivanja drugih aktera, a to je zajednički izbor najbolje metode i rješenja za neko pitanje. Pokazuje se da komunikacija javne uprave $i$ civilnog društva u RH nije dovoljno razvijena. Izostanak ikakve argumentacije i nedostatna argumentacija danih odgovora na komentare (Prkut, 2015) može biti posljedica nezainteresiranosti, ali i nedovoljne 
educiranosti koordinatora savjetovanja o važnosti izgradnje odnosa sa sudionicima u postupcima. Od ukupno 18.767 pristiglih komentara u postupcima savjetovanja provedenih u 2014. samo ih je 17,9\% prihvaćeno, dok je izvješće o provedenom savjetovanju objavljeno za $65 \%$ postupaka. Takve brojke zasigurno su utjecale na pad aktivnosti civilnog društva pa je godinu kasnije broj podnositelja komentara smanjen za $21 \%$, a broj komentara za $17,89 \%$. Organizacije civilnog društva zainteresirane su za promjene i sudjelovanje, međutim slaba komunikacija znatno oslabljuje efekte koje suradnja javne uprave i civilnog društva treba proizvesti. Posljednji od problema koji se ističe u provedbi instrumenta savjetovanja je vidljivo smanjenje rasta provedenib postupaka odnosno tendencija ka opadanju. Nakon formiranja instrumenta savjetovanja, a posebno nakon uvođenja pravne sankcije, mogao se primijetiti velik rast provedbe s naglaskom na državna tijela, pa je tako u periodu 2010.-2014. broj savjetovanja porastao sa 48 na 544 po godini. ${ }^{36}$ Prošle godine rast se uvelike usporio, što pokazuje porast od samo $12 \%$ prema godini prije. ${ }^{37} \mathrm{U}$ okviru ZPUPa broj provedenih savjetovanja smanjen je za $37,5 \%$. Vidljiv je postupni pad entuzijazma nakon početnih godina kod, posebno, aktera zainteresirane javnosti, pa ovi podaci trebaju biti indikatori potrebe za određenim funkcionalnim modifikacijama, ali i nužnosti kontinuiranog rada na održavanju aktivnosti i razine zainteresiranosti kako bi se izbjegao daljnji pad količine provedenih savjetovanja u narednim godinama.

\section{Prijedlozi za poboljšanje provođenja i kvalitete postupaka savjetovanja sa zainteresiranom javnošću}

Na temelju do sada iznesenih podataka i činjenica o karakteristikama i provedbi instrumenta savjetovanja sa zainteresiranom javnošću u RH, moguće je definirati određene prijedloge za poboljšanje. Prijedlozi se

${ }^{36}$ HANFA je u 2014. provela najviše postupaka savjetovanja (104), zatim Ministarstvo poljoprivrede (52) te Ministarstvo zaštite okoliša i prirode (45).

37 Prema izvješću za 2015. najviše postupaka savjetovanja provedeno je o nacrtima pravilnika (312), zatim o nacrtima zakona (123), o nacrtima uredbi (34) te o nacrtima strateških dokumenata (30). Među državnim tijelima koja su provodila savjetovanja ističu se Ministarstvo poljoprivrede (61), Ministarstvo pravosuđa (57), HANFA (50), Ministarstvo zaštite okoliša (47) te Ministarstvo zdravlja (46). 
mogu grupirati prema tome je li njihov učinak usmjeren na povećanje broja i širenje opsega postupaka savjetovanja odnosno na podizanje kvalitete.

Prijedlozi za povećanje kvantitete i proširenje opsega postupaka savjetovanja jesu: a) jačanje provedbe mehanizmima poticanja i b) proširenje obvezatnosti provedbe savjetovanja.

Prijedlozi za povećanje kvalitete postupaka savjetovanja jesu: a) kontinuirana revizija i modernizacija; b) jačanje personalnih kapaciteta i c) razvoj partnerskog odnosa javne uprave i civilnog društva.

Provedba postupaka savjetovanja sa zainteresiranom javnošću mogla bi se popraviti krutim i mekim mehanizmima poticanja. Pravno sankcioniranje neprovođenja zakona koje bi zasigurno potaknulo barem dio obveznika na pridržavanje propisanih normi trebalo bi se provoditi dosljednije. Također, zanimljiva su opcija i određeni mekši mehanizmi poticanja provođenja postupaka savjetovanja. Instrumenti kojima bi se moglo utjecati na kvantitetu postupaka savjetovanja jesu različite procjene i samoprocjene čijim bi se uspostavljanjem jednostavno moglo definirati najuspješnije i najneuspješnije provoditelje postupaka te bi se takvi podaci povezali s nagradama za kvalitetu na različitim razinama. To bi imalo poticajni učinak zato što bi javnom deklaracijom o uspjehu mnogi željeli biti uspješniji, a još bi više bilo onih koji bi se trudili da ne budu među najgorima.

Tako bi, primjerice, skraćivanje roka za održavanje savjetovanja moralo postati rijetka iznimka temeljena na dobro obrazloženom razlogu, čime bi se olakšalo snaženje relevantnosti postupka i izgradnja povjerenja građana $\mathrm{u}$ navedene instrumente. Također, poseban naglasak morao bi se staviti na postupke savjetovanja sa zainteresiranom javnošću u JLS, gdje je vrlo slabo provođenje savjetovanja prema ZPPI-ju.

Neki postupci odlučivanja vrlo su malo ili nikako do sada omogućavali participaciju zainteresiranoj javnosti pa bi i na njih trebalo proširiti mogućnost sudjelovanja. Broj propisa za koje se, u okviru godišnjeg plana normativnih aktivnosti, provodi procjena učinaka propisa potrebno je povećavati, a postotak propisa koji se donose po hitnom postupku sa zaobilaženjem provedbe savjetovanja nužno je smanjiti kako bi što više zakona u svojem nastajanju prolazilo kroz konstruktivnu i opširnu javnu raspravu. ZPUP je potrebno proširiti na postupke izrade drugih propisa (strategija, planova itd.) i akata JLS te standardizirati model savjetovanja pri izradi svih vrsta regulative za koje se traži mišljenje javnosti. Posebno bi se, u smjeru daljnjeg povećanja opsega sudjelovanja nedržavnih aktera u odlučivanju, trebalo razmotriti mogućnosti njihova uključivanja u procese donošenja 
izvršnih odluka Vlade i ministarstava, ${ }^{38}$ gdje zainteresirana javnost do sada nije imala gotovo nikakve mogućnosti utjecaja na kreiranje odluka i iskazivanje mišljenja.

Kada se govori o kvaliteti savjetovanja koja se provode, bitno ih je neprekidno revidirati $i$ modernizirati kako bi se koristili trenutačno najbolji odnosno eliminirali nefunkcionalni i zastarjeli mehanizmi. Najviše korištena metoda je internetsko savjetovanje, što je za sudjelovanje jednostavan i dostupan način svakome. Provedba savjetovanja, međutim, ne treba biti fokusirana samo na na internetsko savjetovanje, već je tijelima javne vlasti omogućen niz metoda ${ }^{39}$ putem kojih svaka može prema svojim preferencijama i mogućnostima odrediti dodatne oblike interakcije sa zainteresiranom javnošću i dobivanja potrebnih mišljenja i preporuka. Potrebno je istraživati i razvijati nove aktualnije metode savjetovanja, a internetsko savjetovanje dodatno pojednostavniti i usavršavati da bi se više olakšalo i motiviralo sudjelovanje većeg broja zainteresiranih dionika. Valjalo bi razmotriti mogućnosti dodatnog produljenja vremenskog roka za savjetovanje. Uključivanje je potrebno proaktivno poticati i putem različitih komunikacijskih sredstava široke otvorenosti poput društvenih mreža (npr. Facebook i Twitter) i drugih sličnih oblika prijenosa informacija i poziva na sudjelovanje većem krugu potencijalnih interesenata.

Nužno je ojačati personalne kapacitete, posebice najnižih razina vlasti za provođenje postupaka savjetovanja. Korisno je organizirati što veći broj edukacijskih programa i radionica ${ }^{40}$ sa JLS i drugim tijelima koja provode savjetovanja. Takvi programi razvijaju sposobnosti koordinatora za pravilno vođenje i kvalitetniju komunikaciju s drugim akterima. Edukacija bi trebala biti što raznovrsnija, usmjerena na tehnike i vještine potrebne za koordinaciju savjetovanja, a u okviru toga trebalo bi organizirati provjeru usvojenog znanja i certificiranje pohađanja edukacije. Službenike koji koordiniraju postupcima savjetovanja treba međusobno povezivati da bi se formirale stabilne mreže koordinatora putem kojih će se razmjenjivati međusobna iskustva, dobra praksa te na taj način posredno povećavati i kvaliteta provedenih postupaka savjetovanja. Kvalitetu danih odgovora

\footnotetext{
38 Postupci savjetovanja provodili su se tako u 2015. samo za uredbe koje se donose na temelju posebnih zakona, i to za ukupno njih $20 \%$ u minimalnom vremenskom trajanju od 7 do 15 dana (Izvješće, 2015)

39 Metode savjetovanja koje se koriste su raznolike: javne rasprave; stručni sastanci; predstavljanja; konferencije; okrugli stolovi; fokus grupe i forumi (Musa, 2015). macijama.

${ }^{40} \mathrm{http} / / / \mathrm{www}$.pristupinfo.hr/edukacije-o-primjeni-zakona-o-pravu-na-pristup-infor-
} 
s naglaskom na one za odbačene komentare i prijedloge treba detaljnije pratiti da bi se smanjio broj nedovoljno argumentiranih odgovora što ne djeluje poticajno na aktere za daljnje konstruktivno sudjelovanje u novim postupcima. Organizacije civilnog društva morale bi resurse usmjeriti prema izgradnji vlastitih kapaciteta, stručnog znanja i evaluativnih sposobnosti da bi se što efikasnije mogle oduprijeti marginalizaciji tijekom policy procesa odnosno da bi se što svrsishodnije mogle aktivirati u postupcima participiranja u odlučivanju, davati kvalitetnije i upotrebljive prijedloge i tako utjecati na donošenje odluka.

Svrha i smisao provođenja savjetovanja sa zainteresiranom javnošću u potpunosti se mogu ostvariti kada i ako se izgradi stabilan odnos partnerstva javne uprave i civilnog društva. Za takav napredak potrebno je stvarati percepciju organizacija civilnog društva kao suradnika javne uprave, partnera i nezaobilaznog faktora u procesu odlučivanja. Stalnost i vidljivost pune podrške javne vlasti od velikog je značenja jer se na taj način potiče sve potencijalne dionike i aktere na aktivnije i temeljitije participiranje, a u fokusu šire javnosti uključivanje civilnog društva bolje se razumije kao nešto što je poželjno i korisno. Razvoj odnosa partnerstva među akterima u odlučivanju koristit će povećanju povjerenja građana u javnu upravu, efikasnosti, transparentnosti i kvaliteti donesenih odluka, dodatnom otvaranju procesa i institucija u odlučivanju, uzajamnom poštovanju i toleranciji različitih društvenih grupa.

\section{Zaključak}

Društvo i institucije nakon dugog su se niza godina provedenih unutar totalitarnog sustava postupno i vrlo polako demokratizirali, kroz autokratsku vladavinu, ratna razaranja i vrlo grubu i neplansku privatizaciju 1990ih. Proces demokratizacije traje i dalje, a egzistiranje funkcionalnog civilnog društva ovisi o stupnju političke kulture, količini društvenog kapitala i nizu drugih faktora. Civilno društvo još nije na visokoj razvojnoj razini, kao što je to slučaj u nekim razvijenim demokracijama s dugom tradicijom progresivnog razvoja civilnog društva poput, primjerice, Nizozemske ili Njemačke. Također, neke države sa sličnim povijesnim razvojem i putem kao RH (npr. Estonija) ostvarile su do sada puno veći napredak u razvoju civilnog društva.

Međutim, namjera implementiranja politike savjetovanja sa zainteresiranom javnošću u pravni sustav RH pozitivan je znak usmjerenja prema modernizaciji vlasti i društva. Vidljiv je pomak institucija vlasti prema iz- 
gradnji europskog stila uključivog odlučivanja te društva zasnovanog na dijalogu i participaciji. Dosljedno provođenje i konstantno usavršavanje postupaka savjetovanja, zatim definiranje jasne vizije i dugoročna strategija razvoja civilnog društva te izgradnja uzajamno uvažavajućeg otvorenog odnosa i partnerske suradnje nailaze na poteškoće i određene zamjerke, ali sadržavaju i dovoljnu količinu potencijala za budući daljnji razvoj civilnog društva, javne vlasti, ali i političke kulture i demokracije u RH. Regulacijska reforma u RH pomogla je prilagodbu regulative RH postojećim europskim standardima i postavljanju temelja za kvalitetniju i efikasniju buduću regulativu prema uzoru na EU-u. U toj sferi RH je napredovala, no empirijski pokazatelji posljednjih godina pokazuju da mnogi problemi još uvijek postoje pa će biti potrebno uložiti mnogo truda od strane javne vlasti, ali i organizacija civilnog društva, da bi se u potpunosti razvio funkcionalan i efikasan sustav savjetovanja sa zainteresiranom javnošću u izradi zakona, drugih propisa i akata.

\section{Literatura}

Banić, S. (2009). Kapaciteti regulacijskog menadžmenta u tranzicijskim zemljama. Hrvatska javna uprava, 9(3), 617-626.

Bardet, C. (2012). Priručnik za savjetovanje sa zainteresiranom javnošću. Preuzeto s mrežne stranice Ureda za udruge Vlade Republike Hrvatske: https://udruge. gov.hr/UserDocsImages/userfiles/file/Prirucnik\%20za\%20savjetovanje.pdf

Barić, S. \& Dobrić, D. (2012). Europeizacija civilnog društva u RH: Shvaćanje socijalnog kapitala ozbiljno? Zbornik Pravnog fakulteta Sveučilišta u Rijeci, 33(2), 883-916.

Bežovan, G. (2003). Vrednote civilnog društva u Hrvatskoj. Nova prisutnost, 1(2), 237-256.

Butković, H. (2004). European Union and its Civil Society: A Neverending Search for Accountability. Politička misao, 41(5), 95-103.

Džinić, J. (2011). Regulacijska tijela i regulacija: neki problemi u pogledu (ne) donošenja uredbi za izvršenje zakona. Hrvatska $i$ komparativna javna uprava, 11(3), 651-680.

Europska komisija (2014). Stakebolder consultation guidelines 2014. Preuzeto s mrežne stranice Europske komisije:ec.europa.eu/smartregulation/impact/ docs/scgl_pc_questionnaire_en.pdf

Europska komisija (2015). Better Regulation Guidelines. Preuzeto s mrežne stranice Europske komisije: http://ec.europa.eu/smart-regulation/guidelines/docs/ swd_br_guidelines_en.pdf 
Heidbreder, E. G. (2012). Civil Society Participation in EU Governance. Living reviews in european governance, 7(2), 1-42.

Horvatić, M. (2006). Komunikacijska strategija za informiranje brvatske javnosti o Europskoj uniji i pripremama za članstvo. Zagreb, Hrvatska: Republika Hrvatska, Ministarstvo vanjskih poslova i europskih integracija

Koprić, I., Marčetić, G., Đulabić, V., \& Lalić Novak, G. (2014). Upravna znanost: javna uprava u suvremenom europskom kontekstu. Zagreb, Hrvatska: Pravni fakultet Sveučilišta u Zagrebu, Studijski centar za javnu upravu i javne financije

Lalić Novak, G. (2010). Hrvatska uprava u izvješćima Europske komisije i SIGME 2010: ograničen napredak u reformi javne uprave. Hrvatska javna uprava, 10(4), 927-940.

Musa, A. (2015). Prilagodba procesa izrade propisa europskim integracijama: novine i izazovi. Godišnjak Akademije pravnih znanosti Hrvatske, 6(1), 3-40.

Održivi razvoj zajednice (2012). Imaju li građani što za reći? Sudjelovanje organizacija civilnog društva u donošenju odluka na lokalnoj razini. Preuzeto s mrežne stranice ODRAZ-a: http://odraz.hr/media/131001/odraz_brosura_gradani_ web.pdf

OECD Sigma (2011). SIGMA Assessment Croatia. Preuzeto s mrežne stranice Sigme: http://www.sigmaweb.org/publications/48970754.pdf

Petek, A. (2009). Policy mreže i regulatorna reforma. Magistarski rad, Fakultet političkih znanosti Sveučilišta u Zagrebu. Preuzeto s mrežne stranice Hrvatske znanstvene bibliografije: https://bib.irb.hr/datoteka/427230.Magistarski_ rad_Ana_Petek.pdf

Prkut, D. (2015). Uređenje referendumskog pravnog okvira-onemogućavanje građanskih referenduma. Političke analize, 6(21), 11-21.

Puljiz, V. (2000). Civilno društvo u svijetu i u Hrvatskoj, U: S. Baloban (ur.) Izazovi civilnog društva u Hrvatskoj (str. 13-30). Zagreb, Hrvatska: Centar za promicanje socijalnog nauka Crkve, Kršćanska sadašnjost.

Renda, A. (2008). Advancing the better regulation agenda: selected challenges for Europe. Preuzeto s mrežne stranice Social Science Research Network: http:// papers.ssrn.com/sol3/papers.cfm?abstract_id $=1291030$

Scharpf, F. W. (1997). Balancing Positive and Negative Integration: The Regulatory Options for Europe. Preuzeto sa mrežne stranice Max Planck Institute for the study of Societies: http://www.mpifg.de/pu/workpap/wp97-8/wp97-8.html

Smismans, S. (2003). European Civil Society: Shaped by Discourses and Institutional Interests. European Law Journal, 9(4), 482-504.

Škrabalo, M. (2012). Transparency in retrospect: preliminary lessons from Croatia's EU accession process. Preuzeto s mrežne stranice Franziske Brantner: http://www. franziska-brantner.eu/wp-content/uploads/2012/11/Transparency-in-retrospect.pdf

Ured za udruge Vlade Republike Hrvatske (2010). Smjernice za primjenu Kodeksa savjetovanja sa zainteresiranom javnošću u postupcima donošenja zakona, drugih propisa $i$ akata. Zagreb, Hrvatska: Ured za udruge Vlade Republike Hrvatske 
Vidačak, I. (2011). Impact of Europeanization on Interest Groups Access and Representation in the Policy making Process in Croatia. Preuzeto s mrežne stranice Etudes Europeennes: http://www.etudes-europeennes.eu/images/stories/A look_at_Croatia/ENA-igor-vidacak-final_draft-0809_291111js_FINAL.pdf

Vidačak, I. (2013). Towards More Open, Inclusive and Effective Policy MakingInstitutuionalising Public Consultations in Croatia. U J.H. Meyer-Sahling (ur.) Effective Policy Making: How to Ensure Desired Changes through Successful Implementation of policies (str. 82-94). Danilovgrad, Crna Gora: Regional School of Public Administration

Vidačak, I. \& Škrabalo, M. (2014). Exploring the Effects of Europeanization on the Openness of Public Administration in Croatia. Hrvatska $i$ komparativna javna uprava, 14(1), 149-187.

\section{Propisi Europske unije, Republike Hrvatske i međunarodnih organizacija}

Agreement (2016). Interinstitutional Agreement of Better Law-Making of the European Parliament, the Council and the European Commission of 13. April 2016. Preuzeto s mrežne stranice Europske komisije:http://ec.europa.eu/smartregulation/better_regulation/documents/iia_blm_final_en.pdf

Decision (2004). Decision 2004/100/EC of the Council of the European Union establishing a Community action programme to promote active European citizenship (civic participation), OJ, L 30/6, 4.2.2004, str. 6-14.

EK (2000). Discussion Paper: The Commission and non-governmental organisations:building a stronger partnership. COM (2000) 11 final. European Commission.

EK (2002). Communication from the Commission- Towards reinforced culture of consultation and dialogue- General principles and minimum standards for consultation of interested parties by the Commision, COM (2002) 0704 final. European Commission.

EK (2001). Europska vladavina: Bijela knjiga, COM (2001) 428 final. Europska Komisija.

Kodeks savjetovanja sa zainteresiranom javnošću u postupcima donošenja zakona, drugih propisa i akata, NN 140/09

Odluka o osnivanju Savjeta za razvoj civilnog društva, NN 140/09

Poslovnik Hrvatskoga sabora, NN 81/13

Sporazum o osnivanju Gospodarsko-socijalnog vijeća, NN 149/09

Strategija suzbijanja korupcije za razdoblje od 2015. do 2020., NN 26/15

Treaty of Lisbon amending the Treaty on European Union and the Treaty establishing the European Community (OJ C 360/01, 17.12.2007, str. 1-231). 
Convention on information, public participation in the process of decision making and access to justice in environmental matters of the United Nations, Economic Commission for Europe of 25. June 1998. Preuzeto s mrežne stranice UNECE-a: https://www.unece.org/fileadmin/DAM/env/pp/documents/ cep43e.pdf

Uredba o provedbi postupka procjene učinaka propisa, NN 66/12

Uredba o Uredu Vlade Republike Hrvatske za udruge, NN 132/98

Ustav Republike Hrvatske, NN 56/90, 135/87, 8/98, 113/00, 124/00, 28/01, 41/01, 55/01, 76/10, 85/10, 05/14

Zakon o Nacionalnoj zakladi za razvoj civilnog društva, NN 173/03

Zakon o procjeni učinaka propisa, NN 90/11

Zakon o pravu na pristup informacijama, NN 25/13, 85/15

Zakon o udrugama, NN 70/97

Zakon o zaštiti okoliša, NN 110/07

\section{Web izvori}

www.eacea.ec.europa.eu

www.ec.europa.eu

www.opengovpartnership.org

www.pristupinfo.hr

www.registri.uprava.hr

www.savjetovanja.gov.hr

www.strategija.udruge.hr

www.udruge.gov.hr

www.vlada.gov.hr

www.zaklada.civilnodrustvo.hr

www.webgate.ec.europa.eu 


\section{COOPERATION BETWEEN CIVIL SOCIETY AND PUBLIC ADMINISTRATION IN PUBLIC CONSULTATIONS}

\section{Summary}

The strengthening of the regulatory state concept in recent decades bas changed the role of public authorities in the decision-making process, rendering them just one of the many different participants involved in policy-making and the decision-making process. As regulation became their primary function, public authorities began to emphasise the quality of the decision-making process and the decisions it engenders in order to encourage the establishment of a suitable environment for economic development. Therefore, supranational organisations and many countries are implementing regulatory reforms in an attempt to create better regulation, and in the context of these reforms they are using instruments of civil society participation in decision-making. As a result of various circumstances, creating relations with civil society based on cooperation and partnership is often a relatively slow and gradual process, yet progress is notable. The European Union is constantly evolving opportunities and ways in which various civil society organisations can convey their opinions about the adoption of certain decisions at the EU level. Croatia has also, particularly over the last seven years, tried to follow this trend by defining the legal provisions and procedures of public consultations, and by establishing mechanisms for cooperation with civil society organisations and many other stakebolders in the drafting of laws and other regulations. The paper analyses the role of civil society and the opportunities for public consultations in the European Union and Croatia. The analysis results indicate progress as well as problems. The author suggests improvements with regard to the cooperation between civil society and public administration in public consultations.

Keywords: civil society, public consultations, decision-making process, stakebolders, participation 